\title{
A DITADURA MILITAR E A PROLETARIZAÇÃO DOS PROFESSORES
}

\author{
Amarilio Ferreira Jr. ${ }^{*}$ \\ MARISA BITTAR*
}

\begin{abstract}
RESUMO: Este artigo aborda as transformações ocorridas no magistério durante o regime militar (1964-1985), mostrando que a sua origem deixou de ser exclusivamente as classes médias urbanas e fraçōes das elites, passando a constituir-se também das camadas populares. Ocorreu, assim, um processo de mobilidade tanto ascendente quanto descendente, pois os que tinham origem nos "de cima" se proletarizaram enquanto os de origem popular ascenderam a uma profissão da classe média. A nova categoria, formada por essas duas fraçōes, foi submetida a condições de vida e de trabalho determinadas pelo arrocho salarial. Analisamos este fenômeno tomando por base a Confederação dos Professores Primários do Brasil, que, por força das reformas educacionais da ditadura, cresceu numericamente e se transformou na Confederação dos Professores do Brasil. A profissão, em decorrência dessa rápida e profunda transformação, passou a sofrer uma crise de identidade - a meio caminho da proletarização e do exercício intelectual.
\end{abstract}

Palavras-chave: Ditadura militar. Professores. Sindicalismo.

\section{THE MILITARY REGIME AND TEACHER's PROLETARIANIZATION}

ABSTRACT: This paper explores the transformation suffered by the teacher category during the military regime (1964-1985). It shows that teachers did not originate exclusively from the urban middle classes and fractions of the economical elite, but also from popular classes. An ascendant and descendant social mobilization process

\footnotetext{
* Doutor em História Social pela Universidade de São Paulo (USP) e professor do Departamento de Educação da Universidade Federal de São Carlos (UfSCAR). E-mail: ferreira@power.ufscar.br

** Doutora em História Social pela USP e professora do Departamento de Educação da UFSCAR. E-mail: bittar@power.ufscar.br
} 
thus took place: those who originated from "upper" classes became proletarianized, while those from popular origin rose to a middle class profession. This new category, made up by these two sections, was submitted to standards of life and work determined by salary tightening. The analysis of this phenomenon is here carried out taking as a starting point the Confederation of Brazilian Primary Teachers, which, due to the dictatorship's educational reforms, grew numerically and transformed itself into the Confederation of Brazilian Teachers. Owing to this quick and profound transformation, the profession suffered, from then on, an identity crisis - moving towards the proletarianization of intellectual practice.

Keywords: Military dictatorship. Teachers. Unionism.

\section{Introdução}

$\mathcal{E}$

stamos completando vinte anos da conquista do Estado de Direito democrático, mas os efeitos da ditadura militar sobre a educação brasileira ainda não desapareceram. Se considerarmos como traço distintivo da nossa história a descontinuidade sem ruptura, ou seja, a passagem de uma ordem institucional para outra, conservando elementos estruturais da anterior, é possível que encontremos aí a explicação para determinadas permanências. Pelo fato de que o presente ainda conserva elementos daquele passado, é que voltamos a este tema da pesquisa educacional brasileira.

Remontando à criação do Instituto Nacional de Estudos Pedagógicos (INEP), em 1938, e, portanto, bem anterior à sua implantação no âmbito das universidades, a pesquisa educacional no Brasil registra temas e períodos cujos estudos já atingiram um nível elevado de conhecimento. Sem exagero, podemos afirmar, por exemplo, que é o caso da Escola Nova, que tem se revelado um campo no qual a maturidade e a continuidade dos estudos são marcantes. Outros períodos não têm despertado o mesmo interesse. A título de ilustração, examinando o rol de trabalhos apresentados nos encontros bienais da Sociedade Brasileira de História da Educação, verificamos que são bastante reduzidos os estudos sobre a educação no Brasil colonial, situação um pouco diferente para o período do século XIX.

De modo geral, é a República o período sobre o qual tem recaído a maioria dos estudos, sendo que, no seu interior, constata-se a exis- 
tência de temas ou políticas mais presentes no universo da pesquisa educacional, como assinalamos a propósito dos ideais da Escola Nova, enquanto outros assuntos, como a educação sob a ditadura militar, objeto deste artigo, ainda estão longe de serem esgotados.

Dessa forma, completados quarenta anos do golpe militar, em 2004, pensamos ser oportuna a reflexão sobre o impacto da ditadura na educação brasileira, notadamente na escola pública, a mais atingida pelo autoritarismo. Foi ela também a mais sujeita à ideologia tecnocrática subjacente às políticas educacionais emanadas pelo Estado a partir da destituição do presidente João Goulart e da derrocada do nacionalpopulismo, desfecho traumático do processo que se desenrolava desde 1930.

A política educacional do regime militar abrangeu, ao longo dos seus vinte e um anos de duração, todos os níveis de ensino, alterando a sua fisionomia e provocando mudanças, algumas das quais visivelmente presentes no panorama atual. Pautado pela repressão, o Estado editou políticas e práticas que, em linhas gerais, redundaram no tecnicismo; na expansão quantitativa da escola pública de $1^{\circ}$ e $2^{\circ}$ graus às custas do rebaixamento da sua qualidade; no cerceamento e controle das atividades acadêmicas no interior das universidades; e na expansão da iniciativa privada no ensino superior. Reexaminando o conjunto dessas políticas, podemos afirmar que a educação, tal como ocorrera na ditadura Vargas (1937-1945), porém, em maior escala, foi totalmente instrumentalizada como aparelho ideológico de Estado. Sob uma ditadura que perseguiu, prendeu, torturou e matou opositores, a escola foi um dos meios mais eficazes de difusão da ideologia que respaldou o regime militar.

Entre os vários aspectos que marcaram a educação brasileira nesse período, abordaremos aqui o impacto da política educacional do regime militar (1964-1985) sobre a categoria dos professores públicos estaduais, realçando dois aspectos que, interligados, determinaram uma transformação radical na sua trajetória e composição: a) o seu crescimento numérico; b) o arrocho salarial a que foi submetida durante toda a vigência da ditadura.

Numa sociedade que se modernizava pela via autoritária, esses dois fatores, conjugados entre si, atuaram no sentido de torná-la a maior categoria profissional do país e de conferir-lhe uma identidade de 
oposição ao próprio regime. Neste sentido, ela se distingue dos traços que a caracterizavam até então, sobretudo a de ter sido uma categoria profissional pequena, com origem social proveniente das camadas médias e até da elite, não afeita à organização sindical. Tomamos como objeto privilegiado de estudo a Confederação dos Professores Primários do Brasil (СРРВ), criada em 1962, que ilustra bem esses dois momentos, na medida em que, por força das próprias reformas educacionais da ditadura, transformou-se em Confederação dos Professores do Brasil (СРВ), abrangendo os docentes do antigo ginásio e os do $2^{\circ}$ grau, criado pela reforma de 1971.

O termo proletarização será tratado ao longo do texto de modo a mostrar a condição socioeconômica a que foi submetida a nova categoria docente pelas políticas da ditadura militar. ${ }^{1}$ Se no passado os professores da escola pública brasileira provinham das classes médias e altas, a situação atual é bastante distinta e lembra a definição de Wright Mills (1979, p. 147), para quem "os professores, especialmente os do primário e secundário, são, do ponto de vista econômico, os proletários das profissões liberais". No caso brasileiro, entretanto, a proletarização do professorado não significou apenas o empobrecimento econômico, mas também a depauperação do próprio capital cultural que a antiga categoria possuía, ou seja, a velha formação social composta de profissionais liberais - como advogados, médicos, engenheiros, padres etc. constituía um cabedal cultural amealhado em cursos universitários de sólida tradição acadêmica. Ao contrário, as licenciaturas instituídas pela reforma universitária do regime militar operaram um processo aligeirado de formação com graves conseqüências culturais.

As reformas educacionais do regime militar e o novo perfil do professorado brasileiro

A situação do magistério brasileiro na primeira metade dos anos de 1960, de modo geral, apresentava os mesmos contornos sociais das décadas anteriores, particularmente quanto ao fato de que essa categoria continuava sendo um reduto feminino (Lourenço Filho, 1945, p. 400). A conjugação entre perfil feminino e padrão de ensino seletivo era um dos traços dos "anos dourados" da educação brasileira, cujo auge foi exatamente a década de 1960. 
Quanto à formação das professoras, as Escolas Normais, chamadas por Jorge Nagle de "ginásios para moças", atraíam, principalmente, jovens das classes mais abastadas. A tendência de constituir-se numa profissão feminina vinha do início do século XX. "Em 1929, para 23.808 alunos matriculados [no ensino pedagógico], 3.041 eram do sexo masculino"; quanto à origem social, o mesmo autor assinalou que "a escola normal era uma instituição destinada à educação das moças burguesas” (Nagle, 1985, p. 269). Apesar da preponderância dos professores primários, entretanto, uma fração residual de docentes públicos estaduais com formação universitária já dava mostras de seu crescimento. Depois, a partir de 1970, eles constituiriam a base do magistério público estadual de $1^{\circ}$ e $2^{\circ}$ graus.

Assim, a passagem da década de 1960 para a de 1970 foi marcada por mudanças estruturais no sistema nacional de educação. $\mathrm{O}$ regime militar, embalado pelo "milagre econômico", ${ }^{2}$ estabeleceu claramente uma vinculação entre a educação e o modelo autoritário de modernização das relações capitalistas de produção, tal como ficou explícito na mensagem de 31 de dezembro de 1970, do general-presidente Emílio Garrastazu Médici:

Creio que 1971 será um ano de marcante expansão industrial, incentivada pelo programa siderúrgico que dentro de poucos dias apresentarei à Nação (...). Sinto que a grande revolução educacional virá agora, na passagem da velha orientação propedêutica da escola secundária a uma realística preparação para a vida, que atenda à carência de técnicos de nível médio, problema dos mais críticos na arrancada do nosso desenvolvimento. (Médici, 1971, p. 34)

Visando atingir os objetivos propostos, o regime militar implementou duas reformas jurídicas no campo educacional. A Lei n. 5.540, de 28 de novembro de 1968, que reorganizou o funcionamento do ensino superior e sua articulação com a escola média (Saviani, 1987, p. 99); e a Lei n. 5.692, de 11 de agosto de 1971, que reestruturou os antigos primário e ginásio, criando o ensino de $1^{\circ}$ e $2^{\circ}$ graus (idem, ibid., p. 133). Em outras palavras: da junção dos quatro anos do ensino primário com os quatro do ginásio foi criado um único ciclo de oito anos, o chamado $1^{\circ}$ grau de ensino, que passou a ser obrigatório. Quanto aos três anos do antigo ensino colegial, passaram a constituir o $2^{\circ}$ grau. Dessas reformas educacionais começou a emergir a nova configuração profissio- 
nal do professorado público de $1^{\circ}$ e $2^{\circ}$ graus. A primeira lei, no seu artigo 30, estabelecia que: "A formação de professores para o ensino de segundo grau, de disciplinas gerais ou técnicas, bem como o preparo de especialistas destinados ao trabalho de planejamento, supervisão, administração, inspeção e orientação no âmbito de escolas e sistemas escolares, far-se-á em nível superior" (idem, ibid., p. 103).

A reforma universitária de 1968, por intermédio desse artigo, abriu a possibilidade para que uma parte do magistério de $1^{\circ}$ grau - portanto, não só de $2^{\circ}$ grau - fosse formada em cursos do ensino superior, ao contrário da Lei de Diretrizes e Bases da Educação, de 20 de dezembro de 1961, que estipulava uma distinção, nos seus artigos de n. 52 a n. 65 (São Paulo, 1971, p. 62), entre a formação do professor primário, efetivada nas escolas normais ou institutos de educação, e a do professor secundário, realizada nas faculdades de Filosofia, Ciências e Letras.

A Lei n. 5.692/71, na esteira de 1968, foi mais enfática quanto à formação do professor de $1^{\circ}$ e $2^{\circ}$ graus. Entre outros motivos, porque duplicou, de quatro para oito anos, a obrigatoriedade do ensino fundamental a cargo do Estado. O então ministro da educação, coronel Jarbas Gonçalves Passarinho, na sua exposição de motivos, quando da apresentação do anteprojeto de lei ao general-presidente Emílio Garrastazu Médici, afirmou:

Outro capítulo de extrema importância é o "dos professores e especialistas" (...). No que toca à formação, previu-se graduação superior, de duração curta e plena, para o exercício até o $1^{\circ}$ e $2^{\circ}$ graus, respectivamente, e habilitação de $2^{\circ}$ grau para exercício até a metade do $1^{\circ}$. Para o preparo superior de curta duração, reforçando a rede existente, concebeu-se um tipo novo de faculdade, mais modesta, a surgir "nas comunidades menores". Não há dúvidas de que este esquema "permanente" só a longo prazo poderá ser implantado em âmbito nacional. (Passarinho, 1971, p. 19)

Essa política acabou engendrando uma outra composição da categoria profissional dos professores públicos de $1^{\circ}$ e $2^{\circ}$ graus. João Monlevade (1996, p. 144), analisando as conseqüências inauguradas com a Lei n. 5.692/71, afirmou que, na década de 1990, “(...) mais de $50 \%$ [num total de 1,5 milhão] dos professores regentes de classe têm formação de nível superior". Quando da decretação da Lei n. 5.692/71, a professora Thereza Noronha de Carvalho, presidente da СРВ (1972-1978), assinalou que "talvez pela primeira vez em nossa 
História, [ocorrerá] uma verdadeira profissionalização do magistério brasileiro" (СРВ, 1964-1976, p. 51).

Nesse novo contexto da educação brasileira, a СРВ centrou a sua ação no Estatuto do Magistério. É que a Lei n. 5.692/71 previa no seu artigo 36 que cada sistema de ensino teria um Estatuto que estruturasse a carreira dos professores públicos de $1^{\circ}$ e $2^{\circ}$ graus (São Paulo, 1971, p. 9). Com a finalidade de dar cumprimento ao referido artigo, o governo do general Emílio Garrastazu Médici preceituou o Decreto n. 71.244, de 11 de outubro de 1972, estabelecendo normas para a concessão de auxílio do tesouro federal aos sistemas estaduais e municipais de educação (Brasil, 1972, p. 9.186). A medida jurídica adotada pelo regime militar vinculava este último ao artigo 54 da Lei n. 5.692/71, que estipulava as várias formas de ajuda financeira da União para os estados e municípios. Portanto, para que os sistemas estaduais e municipais de educação tivessem acesso às verbas do governo federal era necessário que elaborassem os seus respectivos Estatutos do Magistério.

Entre o final dos anos de 1970 e início dos de 1980, os professores públicos estatuais de $1^{\circ}$ e $2^{\circ}$ graus já se constituíam numa categoria profissional consolidada, perfazendo um contingente numérico superior a um milhão de membros (Milhomem Neto, Documento, B. 80. AO. J). Foi no âmbito do ensino de $1^{\circ}$ grau que se registrou o seu maior desenvolvimento orgânico, em decorrência do ensino de oito séries obrigatórias. Estudo publicado pela Fundação Carlos Chagas dava conta de que "o Brasil possuía em 1982, segundo dados da PNAD, excluindo a zona rural da Região Norte, 899 mil professores de primeiro grau. Destes, 730 mil (81\%) residiam na zona urbana e 169 mil (19\%), na zona rural" (Barreto, 1991, p. 13). Nesse período, a remuneração média mensal dos professores do ensino de $1^{\circ}$ grau (público e privado), levando em consideração o nível de instrução e a média salarial nacional em dólares, era de US\$182,58 (idem, ibid., p. 36).

Nota-se, assim, que nessa época, o professorado já não portava o perfil do passado, numericamente inferior e com origem nas camadas médias urbanas e nas próprias elites. Agora, em decorrência das mudanças estruturais do país e das reformas educacionais citadas, ele passava a ser uma categoria muito pouco assemelhada à anterior e submetida a condições de vida e de trabalho bastante diversas. Em síntese: o crescimento econômico acelerado do capitalismo brasileiro durante a ditadura militar impôs uma política educacional que se materializou, 
em linhas gerais, nas reformas de 1968 e de 1971, cujos efeitos engendraram uma nova categoria docente e, por conseguinte, no exercício da profissão em parâmetros distintos dos anteriores. Os professores formados nos cursos de licenciaturas curtas das faculdades privadas noturnas substituíram a pequena elite intelectualizada das poucas escolas públicas antes existentes. A extensão da escolaridade obrigatória de quatro para oito anos ocasionou a rápida expansão quantitativa da escola fundamental, exigindo, para o seu atendimento, a célere formação dos educadores, o que se deu de forma aligeirada. A combinação entre crescimento quantitativo, formação acelerada e arrocho salarial deteriorou ainda mais as condições de vida e de trabalho do professorado nacional do ensino básico, tanto é que o fenômeno social das greves, entre as décadas de 1970 e 1980, teve como base objetiva de manifestação a própria existência material dos professores públicos estaduais de $1^{\circ} \mathrm{e}$ $2^{\circ}$ graus.

O arrocho salarial foi uma das marcas registradas da política econômica do regime militar. No conjunto dos assalariados oriundos das classes médias, o professorado do ensino básico foi um dos mais atingidos pelas medidas econômicas que reduziram drasticamente a massa salarial dos trabalhadores brasileiros. O processo da sua proletarização teve impulso acelerado no final da década de 1970 e a perda do poder aquisitivo dos salários assumiu papel relevante na sua ampla mobilização, que culminou em várias greves estaduais entre 1978 e 1979. Mariano Enguita, estudando os fatores responsáveis pela proletarização dos professores do ensino básico, considerou que:

A categoria dos docentes (...) compartilha traços próprios dos grupos profissionais com outras características da classe operária. Para sua proletarização contribuem seu crescimento numérico, a expansão e concentração das empresas privadas do setor, a tendência ao corte dos gastos sociais, a lógica controladora da Administração pública e a repercussão de seus salários sobre os custos da força de trabalho adulta. (Enguita, 1991, p. 49)

Um dos aspectos mais relevantes do processo de proletarização vivido pelo magistério brasileiro é que ele desmistificou as atividades pedagógicas do professor como ocupação especializada pertencente ao campo dos chamados profissionais liberais, ocorrendo, de forma acentuada, a paulatina perda do seu status social. A partir desse momento, 
teve início a construção da nova identidade social do professorado do ensino básico, ou seja, a de um profissional da educação submetido às mesmas contradiçôes socioeconômicas que determinavam a existência material dos trabalhadores. Estavam plasmadas, assim, as condições que associariam o seu destino político à luta sindical dos demais trabalhadores.

A transição de uma situação objetiva para outra acarretaria também uma mudança na forma de pensar e agir dos professores. É o que poderíamos chamar de novos processos mentais. Antonio Gramsci, analisando os elementos que interferem nessas transformações da autoconsciência e organização dos grupos sociais, afirmou que:

O primeiro e mais elementar é o econômico-corporativo: (...) sente-se a unidade homogênea do grupo profissional e o dever de organizá-la, mas não ainda a unidade do grupo social mais amplo. Um segundo momento é aquele em que se adquire a consciência da solidariedade de interesses entre todos os membros do grupo social, mas ainda no campo meramente econômico. Neste momento já se coloca a questão do Estado, mas apenas visando a alcançar uma igualdade político-jurídica com os grupos dominantes: reivindica-se o direito de participar da legislação e da administração e, talvez, de modificá-las, reformá-las, mas nos quadros fundamentais já existentes. Um terceiro momento é aquele em que se adquire a consciência de que os próprios interesses corporativos, no seu desenvolvimento atual e futuro, superam o círculo corporativo, de grupo meramente econômico, e podem e devem tornar-se os interesses de outros grupos subordinados. Esta é a fase mais abertamente política, que assinala a passagem nítida da estrutura para a esfera das superestruturas complexas; é a fase em que as ideologias germinadas anteriormente se transformam em "partido", entram em choque e lutam até que uma delas, ou pelo menos uma combinação delas, tende a prevalecer, a se impor, a se irradiar em toda a área social, determinando, além da unidade dos fins econômicos e políticos, também a unidade intelectual e moral. (Gramsci, 1978, p. 49-50)

O comportamento social que caracterizava os movimentos grevistas da categoria dos professores públicos estaduais de $1^{\circ}$ e $2^{\circ}$ graus, no final da década de 1970, era do tipo que já engendrava uma "consciência da solidariedade de interesses gestada entre todos os membros do grupo social" e que questionava, ainda que do ponto de vista econômico, as bases jurídicas do Estado ditatorial brasileiro. Provavelmente, apenas as vanguardas da categoria, em unidades federativas como São 
Paulo, Rio de Janeiro, Minas Gerais, Rio Grande do Sul, Paraná e Pernambuco (Ferreira Jr., 1998, p. 89 passim), tinham atingido o terceiro momento descrito por Gramsci, isto é, "a fase mais abertamente política”; e alcançado, portanto, o amadurecimento social necessário para criar as condiçôes organizativas e de direção política para as lutas levadas a cabo pelos professores nacionalmente.

Do ponto de vista da extração social, a nova categoria dos professores públicos do ensino básico resultou, fundamentalmente, de duas vertentes da estrutura de classes da sociedade brasileira contemporânea. A primeira foi constituída por aqueles que sofreram um processo de mobilidade social vertical descendente, ou seja, pertenciam a certas camadas da burguesia ou das altas classes médias e foram proletarizados econômica e socialmente no curso da monopolização que as relações de produção capitalistas tomaram nas últimas décadas. Já a segunda originou-se de determinadas frações das classes médias baixas ou das camadas dos trabalhadores urbanos que se beneficiaram da expansão da educação universitária, ${ }^{3}$ a partir dos anos de 1970 , e efetivaram uma mobilidade vertical ascendente na pirâmide da estrutura social. Assim, esta última realizou uma trajetória social inversa da primeira, ou seja, teve uma ascensão no seu status social. Para Perseu Abramo, esse fenômeno de mobilidade social apresentou implicações ideológicas em relação ao mundo da educação no qual estavam inseridos os professores, que foram analisadas assim:

Essa segunda [vertente] - para quem ser professor significa quase o apogeu na escala de ascensão social - passa a ter, diante dos problemas da educação e dos problemas da sua corporação profissional, uma atitude bastante diferente da primeira, que se proletarizou no trabalho. A segunda camada, que talvez hoje, em certos centros urbanos do país, constitua a maioria, tem-se mostrado, de certa forma, conservadora e pouco afeita à luta por modificações e transformações na educação e na sociedade. (Abramo, 1986, p. 78-79)

Poder-se-ia pensar que a presença da primeira vertente na composição social dos professores ainda pudesse ser suficiente para manter a profissão no rol dos ofícios liberais. Todavia, esse amálgama social os de cima (franjas burguesas e extratos das classes médias altas), de um lado, e os de baixo (camadas pauperizadas das classes médias e setores do operariado urbano), do outro - não impediu que se instaurasse um processo perverso e contínuo de proletarização da categoria pro- 
fissional dos professores públicos estaduais de $1^{\circ}$ e $2^{\circ}$ graus, tal como ficou enfatizado neste estudo:

Atores de uma sociedade moderna, onde a escolarização é um elemento central do processo de desenvolvimento e a institucionalização das relaçôes de trabalho uma conquista datada, os professores têm sido, nos últimos anos, obrigados a se empenhar em uma luta mortal pela preservação de direitos trabalhistas que, para outras categorias, podem ser considerados como já adquiridos. Ao mesmo tempo foram, talvez, mais intensamente afetados pela proletarização do que qualquer outra categoria de trabalhadores urbanos no Brasil. (Peralva, 1990, p. 158)

O assunto também foi objeto de preocupação de Luiz Antônio Cunha, que, estudando a evolução salarial dos professores do ensino básico em dois dos principais estados da Federação, constatou elementos concretos do processo de proletarização da categoria. Segundo ele,

O professor primário da rede estadual de São Paulo tinha o salário médio por hora equivalente a 8,7 vezes o salário mínimo, em 1967. Já em 1979, esta média havia baixado para 5,7 vezes (...). No Rio de Janeiro, de onde se dispõe de séries mais longas, o salário eqüivalia (no Distrito Federal ou na rede estadual situada no município da capital) a 9,8 vezes o salário mínimo em 1950, despencando para 4 vezes em 1960 e atingindo 2,8 vezes em 1977 (...). Treze anos depois, desceu ainda mais: 2,2 salários mínimos. (Cunha, 1991, p. 75)

Premida pelo achatamento salarial e pela rápida queda no seu padrão de vida e de trabalho, a categoria profissional dos professores públicos de $1^{\circ}$ e $2^{\circ}$ graus foi desenvolvendo uma consciência política que a situava no âmago do mundo do trabalho, tal como já estava posta para a classe operária fabril. Em outros termos: incorporou a tradição da luta operária - nos marcos da expressão sindical - e transfigurou-se numa categoria profissional capaz de converter as suas necessidades materiais de vida e de trabalho em propostas econômicas concretas. Miguel Arroyo, estudando esse processo social, afirmou que:

Nos novos elementos incorporados se destacam aqueles que configuram os professores como trabalhadores, como força de trabalho submetida à lógica mercantil (...). O movimento de professores desvelou uma realidade que o discurso educativo ultrapassado tentava encobrir, uma grande conquista que tem de ser creditada aos professores e suas lutas. (Arroyo, 1991, p. 156) 
Os professores públicos estaduais de $1^{\circ}$ e $2^{\circ}$ graus se constituíram em um dos protagonistas sociais da transição democrática não apenas como uma categoria profissional em si, mas, sobretudo, por meio de uma intervenção programática própria no âmbito da formação societária brasileira no período correspondente às décadas de 1970 e 1980. Nesse contexto, a importância sociopolítica do sindicalismo de professores ganhou relevância porque:

O caráter nacional do movimento de professores caminha no sentido de garantir e especificar um plano nacional de cargos e salários, uma carreira nacional para o magistério de $1^{\circ}$ e $2^{\circ}$ graus na linha conquistada timidamente na Nova Constituição. Os velhos estatutos do magistério, que expressavam formas de gestão em função das especificidades de cada nível de ensino e de administração, vêm perdendo sentido na medida em que o movimento de professores amplia sua expressão nacional e exige o tratamento dos trabalhadores em educação como sujeitos de idênticos direitos, independentemente do tipo de patrão - nação-estado-município-mantenedora - e independentemente da região ser rica ou pobre. (Arroyo, 1990, p. 156)

Posto assim, a categoria dos professores do ensino básico conquistou a identidade sociopolítica que a colocava, nos anos de 1980, como uma das mais importantes interlocutoras da educação pública brasileira. Mas, afinal, quem foi o "demiurgo" estatal que produziu historicamente tal protagonista social? Ou de outra forma: De que natureza era o contexto histórico do pós-64, nos seus traços gerais, sobre o qual se deu a formação da categoria social dos professores públicos estaduais de $1^{\circ}$ e $2^{\circ}$ graus? A natureza do regime militar assumiu a seguinte caracterização institucional: um Estado autoritário, dotado de grande capacidade superordenadora da sociedade civil; um sistema produtivo baseado na grande empresa privada, apoiada por uma importante rede de empresas de serviços públicos; e um ordenamento jurídico orientado no sentido da exclusão seletiva de qualquer influência dos intelectuais, da Igreja, e de grupos organizados de estudantes e trabalhadores, além das organizações de esquerda, ou seja, de quaisquer possibilidades efetivas de oposição.

A conquista das liberdades políticas e o agravamento das condições de vida e de trabalho dos professores

A história contemporânea brasileira contrariou a expectativa segundo a qual a democracia política poderia gerar as condiçóes, tanto 
para a retomada do crescimento econômico, quanto para a adoção de padrōes de distribuição mais igualitários. Efetivamente, confirmou-se a democratização da sociedade brasileira no campo político, mas a institucionalização das liberdades democráticas não foi suficiente para estabelecer a retomada do crescimento econômico e muito menos para instituir uma política de redistribuição de renda. A manutenção e o recrudescimento de traços estruturais do passado, na nova ordem institucional inaugurada com o fim da ditadura militar, impediram que a democratização ultrapassasse os limites do âmbito político. Ao contrário, a total subordinação da política macroeconômica brasileira aos ditames do Consenso de Washington (O Estado de S. Paulo, 1994, p. 2) resultou no agravamento das condições de vida e de trabalho dos professores públicos brasileiros.

O movimento sindical do magistério do ensino básico, organizado pela Confederação dos Professores do Brasil, análogo a um conjunto de outras agências da sociedade civil que se opunham ao regime militar, saiu ganhando no geral, mas perdeu no particular. Ou seja: os professores públicos estaduais ajudaram a conquistar a democracia e, portanto, foram protagonistas importantes do cenário político nacional, mas não tiveram o seu rol de reivindicações específicas atendido pela nova ordem institucional estabelecida.

Posto desse modo, o início do processo de democratização da sociedade brasileira na primeira metade dos anos de 1980 significou a possibilidade histórica da socialização da política, isto é, a incorporação de milhões de brasileiros no processo decisório das grandes questões nacionais. ${ }^{4}$ Entre esses milhões encontrava-se a categoria social dos professores públicos estaduais de $1^{\circ}$ e $2^{\circ}$ graus.

A propósito, é interessante notar que foi a própria dinâmica social reivindicatória desse movimento sindical que inseriu a categoria dos professores públicos de $1^{\circ}$ e $2^{\circ}$ graus no mundo da política nacional. Logo após o golpe de Estado de 1964, os professores ainda guardavam sua feição social anterior, isto é, de extração das classes médias e altas e não afeitos à organização sindical. Nossa pesquisa mostrou que a Confederação dos Professores Primários do Brasil (СРPB), a mais importante entidade docente da época, tinha caráter mais associativista e recreativo do que propriamente sindical e, inicialmente, apoiou o regime militar (Ferreira Jr., 1998, p. 49 passim). Depois, porém, começou a transitar para a oposição, tornando-se, no final da década de 1970 e já transfor- 
mada em Confederação dos Professores do Brasil (СРВ), um dos segmentos mais atuantes da luta pela conquista das liberdades políticas. $\mathrm{Ou}$ seja, colocou-se em oposição ao modelo econômico capitalista que a transformou materialmente na categoria social tal como a conhecemos hoje. Podemos concluir que, originada do conjunto de suas políticas, a categoria dos professores se irrompeu contra a ditadura modernizante do regime militar. Dito de outro modo, a criatura voltou-se contra o criador.

As conseqüências sociais da sua luta sindical, emoldurada por esse contexto, têm uma incidência direta no mundo da escola pública, a escola da maioria dos brasileiros. Assim, desde as massivas greves do final da década de 1970, com a participação da CPB, até a constituição do Fórum Permanente de Valorização do Magistério da Educação Básica e da Qualidade de Ensino, proposto, entre outras entidades, pela Confederação Nacional de Trabalhadores em Educação, ${ }^{5}$ durante o governo do presidente Itamar Franco, ficava estabelecida uma contradição: de um lado, a categoria dos professores públicos estaduais do ensino básico lutando por mudanças estruturais da sociedade capitalista brasileira; e, do outro, os corolários sociais desta mesma luta no âmbito da escola pública.

Se a superação dessa antinomia só pode encontrar um desfecho na plena vigência de uma formação social fundada nos pressupostos das liberdades democráticas, todavia, a institucionalização do Estado de direito não significou a melhoria da qualidade de ensino da escola pública brasileira com o puro e simples fim do regime militar. A história contemporânea da sociedade brasileira, principalmente na questão da educação pública, confirma a tese de Richard Rorty (1998, p. 7), segundo a qual "a derrubada de governos autoritários e o advento da democracia constitucional não bastam para assegurar a igualdade ou a dignidade humanas".

A título de ilustração dessa tese, observamos que, na década de 1990, em todo o país, levas de docentes abandonaram a profissão pela impossibilidade de subsistirem do seu próprio trabalho. Citaremos apenas três casos. Em Mato Grosso do Sul, estado que possui uma das pecuárias mais ricas do Brasil, o então presidente da Federação dos Trabalhadores em Educação, François Vasconcelos, denunciou que "todo dia no Diário Oficial” saía uma lista com nomes de professores exone- 
rados e que "o principal motivo" continuava sendo "o baixo salário" (Correio do Estado, 1995, p. 8). Enquanto isso, no estado de São Paulo, "onde o magistério já foi reduto das mocinhas endinheiradas nos anos 50 ", conforme noticiava a grande imprensa, a política salarial espantava os futuros candidatos a uma vaga de professor, revelando "perda de glamour" à medida que o ensino público caía em descrédito:

Hoje em dia a maioria desses cursos [de magistério] recebe apenas garotas de classe média baixa que, entre trabalhar de balconista em uma loja ou ensinar a cartilha no primário, optam pela sala de aula-mesmo com salários que, em geral, não passam dos R \$230,00 para iniciantes. São elas, mesmo sem grande preparo, que darão aulas na rede pública. ( $O$ Estado de $S$. Paulo, 1997, p. 7)

Finalmente, na cidade do Rio de Janeiro, vamos encontrar a própria figura do professor evadido da profissão devido às condiçôes de vida e de trabalho. Daremos voz a Jorge Souza Santos, um desses ex-professores, cujo depoimento se justifica pela capacidade de síntese sobre uma situação social herdada do regime militar e pelo sentimento de frustração, que, certamente, não é só dele:

As escolas do Rio de Janeiro perdem diariamente sete professores. Os baixos salários, a falta de interesse dos alunos e as péssimas condições de trabalho afastam os professores da rede escolar. No dia 10 de maio [1994] eu fui um dos sete professores a abandonar o magistério. Quando comecei a dar aulas, em 1953, eu tinha orgulho da minha profissão. Era uma carreira difícil e disputada. Até quem sonhava ser professor primário tinha de enfrentar os disputados concursos para o Instituto de Educação. O status do professor era elevadíssimo (...). Eu ganhava bem e tinha uma vida nababesca comparada à que um professor do município tem hoje. Tinha duas empregadas, pude comprar um carro e construir uma casa. Essa boa vida começou a ruir no final da década de 70 . A migração para as grandes cidades gerou uma carência de colégios. $\mathrm{O}$ ingresso às escolas públicas, até então difícil, foi facilitada para atender a população mais pobre. Como a rede do governo passou a atender as classes menos favorecidas, as autoridades começaram a relegar as escolas a segundo plano e a diminuir cada vez mais o salário dos professores. A profissão ficou desprestigiada, gerando desinteresse nos jovens da classe alta e média alta. O nível do magistério caiu social e economicamente. Quem se habilita a dar aulas atualmente são pessoas de mais baixa renda, que não têm vivência nem experiência para lecionar. O despreparo cultural dos novos professores é estarrecedor. (Santos, 1994, p. 122) 
Defrontando-nos com depoimentos como este e remetendo-nos à história da educação brasileira, vêm-nos à mente as esperanças esboçadas pelo Manifesto dos Pioneiros, de 1932, texto muitas vezes criticado pela sua dose de idealismo, pela posição liberal de seus signatários, ou mesmo pela própria concepção de educação que defendeu, mas que, ao mesmo tempo, postulou bandeiras como a da escola pública, estatal e laica para todas as crianças e jovens dos sete aos quatorze anos, que, decorridos mais de setenta anos, ainda não foi concretizada. Infelizmente, esta não é a única batalha sem vitória da nossa educação. Concluímos com um excerto do próprio Manifesto para estabelecer o contraste entre o que foi postulado, no início dos anos de 1930, por um grupo de intelectuais liberais, no âmbito de uma sociedade marcada pelas relações agrárias de produção, e a situação a que, objetivamente, foi relegada a categoria dos professores setenta anos depois:

Todos os professores, de todos os graus, cuja preparação geral se adquirirá nos estabelecimentos de ensino secundário, devem, no entanto, formar o seu espírito pedagógico, conjuntamente, nos cursos universitários, em faculdades ou escolas normais, elevadas ao nível superior e incorporadas às universidades. A tradição das hierarquias docentes, baseadas na diferenciação dos graus de ensino, e que a linguagem fixou em denominações diferentes (mestre, professor e catedrático), é inteiramente contrária ao princípio da unidade da função educacional, que, aplicado às funções docentes, importa na incorporação dos estudos do magistério às universidades, e, portanto, na libertação espiritual e econômica do professor, mediante uma formação e remuneração equivalentes que lhe permitam manter, com a eficiência no trabalho, a dignidade e o prestígio indispensáveis aos educadores. (Azevedo et al., 1960, p. 123)

A possibilidade da "libertação espiritual e econômica do professor, mediante uma formação e remuneração" que lhe confira "dignidade e prestígio", distanciou-se na linha do horizonte quando as políticas da ditadura militar provocaram sobre a categoria docente todo o seu efeito devastador e tiveram seqüência com as políticas neoliberais adotadas a partir do início da década de 90 do século XX.

\section{Conclusão}

Podemos concluir, inicialmente, que a ditadura militar, por meio das duas reformas educacionais aqui tratadas, colocou em extinção a 
antiga carreira (profissionais liberais) e criou a atual categoria dos professores do ensino básico. Este processo foi acompanhado do rebaixamento das condições econômicas, bem como da formação acadêmica dos professores, combinação perversa que vem se constituindo em um dos principais problemas da escola pública.

$\mathrm{O}$ arrocho salarial a que foram submetidos os professores durante o regime militar, aliado à expansão quantitativa das antigas escolas públicas de $1^{\circ}$ e $2^{\circ}$ graus, levou a categoria a transformar as suas associações profissionais, até então de marcante caráter recreativo, em verdadeiros sindicatos que passaram a formular e organizar a luta por melhores condiçôes de vida e de trabalho. A maior expressão desse fenômeno foram as greves de milhares e milhares de professores, a partir do fim da década de 1970, em quase todos os estados da Federação. Esse tipo de movimento, pelo seu ineditismo à época, chamou a atenção da sociedade, que, a despeito de guardar da profissão uma imagem associada à abnegação e ao sacerdócio, apoiou as suas mobilizaçóes.

Do ponto de vista político, as greves, como expressão da democracia participativa da categoria dos professores, representaram, naquele contexto, um instrumento de conquista das liberdades democráticas, porque possibilitavam questionar de forma concreta o Estado ditatorial imposto em 1964. Depois, o problema a ser enfrentado passou a ser de outra natureza, porque, após a derrota da ditadura, em 1985, e a promulgação da Constituição de 1988, a sociedade brasileira conquistou as liberdades políticas, mas, ao mesmo tempo, não foi capaz de compatibilizar essas mesmas liberdades com uma política macroeconômica que se pautasse pela distribuição de renda. Com o agravamento da crise econômica nacional, que se arrastou ao longo da década de 1980, as greves dos professores não conseguiram obter dos governos estaduais e municipais uma política salarial condizente com o seu exercício profissional. A propósito, na segunda metade da década, o movimento associativista reivindicava dos governos pós-regime militar o estabelecimento do piso salarial nacional para a categoria baseado em três salários mínimos. Mas esta foi uma batalha perdida, porque a maioria dos governos estaduais era composta pelas forças retrógradas que haviam apoiado a ditadura militar durante vinte anos e que haviam trocado de lado na última hora, não tendo como princípio, portanto, o comprometimento com a democracia e com as políticas públicas. Data daí o início do esgotamento das greves, que se repetiam, se alongavam, mas não alcançavam o seu objetivo salarial. 
O movimento associativista protagonizado pelos professores durante a chamada transição democrática, entretanto, pode ser classificado como um dos principais fatos da história da educação brasileira contemporânea. Ele teve o mérito de chamar a atenção para a nova realidade da escola pública engendrada pelas políticas educacionais da ditadura militar. O principal corolário decorrente dessas reformas foi, sem dúvida nenhuma, a queda brutal da qualidade de ensino, se comparado com a denominada "idade de ouro" da escola pública, aquela que perdurou, aproximadamente, até a década de 1960 . A nova composição social da categoria dos professores que emergiu da política de expansão quantitativa da escola pública, após 1971, e a conseqüente luta sindical por melhores condições de vida e trabalho foram a mais evidente materialização das profundas mudanças que a educação havia sofrido. A manifestação desse fenômeno significou a entrada definitiva da escola pública brasileira na época da educação de massas.

\section{Recebido em novembro de 2005 e aprovado em maio de 2006.}

\section{Notas}

1. Sobre o processo de proletarização a que foi submetido o professorado do antigo $1^{\circ}$ e $2^{\circ}$ graus, consultar também Ferreira Jr. \& Bittar (2006).

2. Termo cunhado pelo próprio general-presidente Emílio Garrastazu Médici, quando afirmou que "nestes seis anos de ação inflexível em favor do futuro do Brasil, logramos o milagre de reduzir a inflação quatro ou cinco vezes menos, aumentando simultaneamente o ritmo do nosso crescimento, a ponto de chegarmos à taxa entre 7 e 9\%” (Médici, 1970, p. 68).

3. O índice de escolaridade de nível superior no Brasil é um dos mais baixos da América Latina, estando ainda bem inferior às potencialidades e necessidades do país. Ele resulta do crescimento que se iniciou na década de 1960, que registrava apenas cem mil estudantes matriculados. A grande expansão concentrou-se nos anos de 1970, atingindo, no final dessa década, 1,4 milhões de alunos. Hoje, mais de 70\% dos estudantes do ensino superior estão matriculados em instituições privadas (INEP, Censo da Educação Superior, 2004).

4. O mais emblemático episódio político desse período foi o movimento das "Diretas-Já" (1984), cujo objetivo era eleger, pela via direta, o presidente da República. Duas opinióes, situadas em pontos opostos do espectro ideológico brasileiro, confirmam a posição assumida no corpo do texto: (A) Golbery do Couto e Silva asseverou que "os comícios e as marchas foram um magnífico espetáculo de civismo. Foram manifestaçóes raras e empolgantes, com entusiasmo, alegria de humor. (...) sem dúvida, essa campanha mobilizou o maior número de pessoas já visto no país" (Couto e Silva, 1984, p. 8). E (B) Wanderley Guilherme dos Santos afirmou: "mais do que uma demanda política de circunstância, o movimento, porque foi irreprimível, decretou o fim da ditadura. Por esse ângulo, o 
Diretas-Já não fracassou; antes, deu origem a um excepcional período de mobilização e participação" (Santos, 1994, p. 7).

5. Em 1989, a Confederação dos Professores do Brasil "realizou um congresso extraordinário (juntamente com o congresso de outras entidades do magistério), objetivando a unificação dos vários sindicatos docentes dos estados sob uma mesma entidade federativa, que passou a denominar-se Confederação Nacional de Trabalhadores em Educação" (Ribeiro \& Joia, 1992, p. 19). Note-se que a união não se restringiu aos sindicatos docentes, pois o termo "trabalhadores", em substituição a "professores", expressou a concepção sindical hegemônica naquele momento, aspecto que foi bastante polêmico.

\section{Referências bibliográficas}

ABRAMO, P. O professor, a organização corporativa e a ação política. In: CATANI, D.B. et al. (Org.). Universidade, escola e formação de professor. São Paulo: Brasiliense, 1986. p. 77-84.

ARROYO, M.G. O acontecimento em educação: o movimento de professores. In: CENTRO ECUMÊNICO DE DOCUMENTAÇÃO E INFORMAÇÃO. Educação no Brasil: 1987-1988. São Paulo: CEDI, 1991. p. 155-157.

AZEVEDO, F. et al. A reconstrução educacional do Brasil: ao povo e ao governo (O manifesto dos pioneiros da educação nova). Revista Brasileira de Estudos Pedagógicos, Rio de Janeiro, v. 34, n. 79, p. 108127, jul./set. 1960.

BAIXOS salários esvaziam magistério. O Estado de S. Paulo, São Paulo, 20 fev. 1997. Caderno G, p. 7.

BARRETO, A.M.R.F. Professores do ensino de primeiro grau: quem são, onde estão e quanto ganham. Estudos em Avaliação Educacional, São Paulo, n. 3, p. 11-43, jan./jun. 1991.

BRASIL. Poder Executivo. Decreto n. 71.244, de 11 de outubro de 1972. Estabelece normas para a concessão de auxílio financeiro aos sistemas estaduais de ensino. Diário Oficial da União, Brasília, DF, 16 out. 1972. Seção 1, p. 9186.

CONFEDERAÇÃO DOS PROFESSORES PRIMÁRIOS DO BRASIL. Atas da CPB: 1964 a 1976; Conselho de Delegados. Brasília, DF: CNTE [s.d.] 100p. (Arquivo da Confederação Nacional dos Trabalhadores em Educação).

Educ. Soc., Campinas, vol. 27, n. 97, p. 1159-1179, set./dez. 2006 
CONSENSO de Washington entra em fase de revisão cinco anos depois. O Estado de S. Paulo, São Paulo, 28 ago. 1994. Caderno H, p. 2.

COUTO E SILVA, G. Basta de trapaça. Entrevistador: Elio Gaspari. Veja, São Paulo, p. 8-15, 16 maio 1984.

CUNHA, L.A. Movimentos sociais, sindicais e acadêmicos. In: CunHA, L.A. Educação, Estado e democracia no Brasil. São Paulo: Cortez; Niterói: UFF; Brasília, DF: FLACSO do Brasil, 1991. p. 60-101.

ENGUITA, M.F. A ambigüidade da docência: entre o profissional e a proletarização. Teoria \& Educação, Porto Alegre, n. 4, p. 41-61, 1991.

FERREIRA Jr., A. Sindicalismo e proletarização: a saga dos professores brasileiros. 1998. 302p. Tese (Doutorado em História Social) - Faculdade de Filosofia, Letras e Ciências Humanas, Universidade de São Paulo, São Paulo.

FERREIRA Jr., A. Professores e sindicalismo em Mato Grosso do Sul (1979-1986). Campo Grande: UFMS, 2003. 154p.

FERREIRA Jr., A.; BITTAR, M. Proletarização e sindicalismo de professores na ditadura militar (1964-1985). São Paulo: Edições Pulsar \& Terras do Sonhar, 2006. 112p.

GRAMSCI, A. Maquiavel, a política e o Estado moderno. Trad. de Luiz Mário Gazzaneo. 3. ed. Rio de Janeiro: Civilização Brasileira, 1978. 444p.

LOURENÇO FILHO, M.B. A remuneração dos professores primários. Revista Brasileira de Estudos Pedagógicos, Rio de Janeiro, v. 6, n. 12, p. 398-416, jun. 1945.

MÉDICI, E.G. Nova consciência do Brasil. Brasília, DF: Imprensa Nacional, 1970. 112p.

MÉDICI, E.G. Tarefa de todos nós. Brasília, DF: Imprensa Nacional, 1971. 103p.

MILLS, W. A nova classe média. Trad. de Vera Borda. 3. ed. Rio de Janeiro: Zahar, 1979. 380p.

MILHOMEM NETO, G.S. O combate ao peleguismo e à organização atrelada, na unificação e no avanço das lutas do professorado. Documen- 
to: B. 80. AO. J. Arquivo da Associação dos Professores do Ensino Oficial do Estado de São Paulo).

MONLEVADE, J. Pequenas geografia, história e economia da profissão docente no Brasil. In: Menezes, L.C. (Org.). Professores: formação e profissão. Campinas: Autores Associados; São Paulo: nUPES, 1996. p. $137-158$.

NAGLE, J. A educação na primeira república. In: FAusto, B. (Org.). História geral da civilização brasileira. São Paulo: DIFEL, 1985. t.3, v.2, p. 261-291.

PASSARINHO, G.J. Exposição de motivos do senhor ministro da educação e cultura. In: SÃO PAULO. Secretaria da Educação. Diretrizes e bases para o ensino de $1^{\circ}$ e $2^{\circ}$ graus. São Paulo, out. 1971. p. 15-21.

PERALVA, A.T. Professores: um movimento a se repensar. In: CENTRO ECUMÊNICO DE DOCUMENTAÇÃO E INFORMAÇÃO. Educação no Brasil: 1987-1988. São Paulo: CEDI, 1991. p. 158-161.

PROFESSORES abandonam escolas do Estado. Correio do Estado, Campo Grande, 28 jun. 1995. Caderno 1, p. 8.

RIBEIRO, V.M.; JOIA, O. Trabalhadores em educação: perfil e representação dos delegados ao $23^{\circ}$ Congresso da CNTE. São Paulo: CEDI; Brasília, DF: CNTE, 1992. 80p.

RORTY, R. Duas profecias. Folha de S. Paulo, São Paulo, 24 maio 1998. Caderno Mais!, p. 7.

SANTOS, J.S. Cansei de ser professor. Veja, São Paulo, v. 1350, n. 30, p. 122,27 jul. 1994.

SANTOS, W.G. Movimento provocou mudanças. Folha de S. Paulo, São Paulo, 24 abr. 1994. Caderno 6, p. 7.

SÃO PAULO. Secretaria da Educação. Diretrizes e bases para o ensino de $1^{\circ}$ e $2^{\circ}$ graus. São Paulo, out. 1971. 68p.

SAVIANI, D. Política e educação no Brasil: o papel do Congresso Nacional na legislação do ensino. São Paulo: Cortez; Campinas: Autores Associados, 1987. 158p. 